\title{
To study the prevalence of HIV infection amongst antenatal women in a tertiary care hospital in Gujarat, India
}

\author{
Mahima Jain*, Bhargavkumar K. Nimavat
}

Department of Obstetrics and Gynecology, BJ Medical College, Ahmedabad, Gujarat, India

Received: 21 June 2017

Accepted: 19 July 2017

\section{*Correspondence:}

Dr. Mahima Jain,

E-mail: drmahimajain@yahoo.co.in

Copyright: (C) the author(s), publisher and licensee Medip Academy. This is an open-access article distributed under the terms of the Creative Commons Attribution Non-Commercial License, which permits unrestricted non-commercial use, distribution, and reproduction in any medium, provided the original work is properly cited.

\begin{abstract}
Background: India has an estimated 2.1 million persons living with HIV in 2011. The prevalence of HIV among adult population has consistently declined over the last one decade from $0.4 \%$ in 2000 to $0.27 \%$ in 2011 .HIV transmission from infected mother to baby is known to occur. The effective use of Antiretroviral drugs is known to reduce the risk significantly.

Methods: This is a retrospective data analysis to know the prevalence of HIV infection among antenatal women attending a tertiary care hospital. All antenatal females are offered pretest counseling, sample collected and tested as per NACO guidelines by Rapid test and ELISA. Results of the test are disclosed after posttest counseling and kept confidential.

Results: The seroprevalence over five years in the present study ranges from $0.466 \%$ to $0.278 \%$. Women in the age group 21-25 years shows high prevalence due to peak sexual activity in this age group. $56.66 \%$ Husbands of these females are reactive which shows the major source of infection.

Conclusions: The present study stresses the need to target the population mainly between 21-30 years in various Government programmes, thereby to reduce the transmission from parent to child.
\end{abstract}

Keywords: Antenatal females, HIV infection

\section{INTRODUCTION}

The Prevalence of HIV among the adult population has continued a steady decline at the national level from an estimated peak of $0.4 \%$ in year 2000 down to $0.26 \%$ in the year $2015 .^{1}$ The mother to child transmission of HIV during pregnancy or breastfeeding is the primary cause of HIV infection among children. It is estimated that without any intervention, the risk of transmission of HIV from infected mother to her child is between $20 \%$ and $45 \%$.

The goal of PPTCT services is to detect more than $80 \%$ HIV infected pregnant women in India. Also, to provide access to comprehensive PPTCT services to more than $90 \%$ of the detected pregnant women. ${ }^{2}$

The newer recommendations are to administer lifelong ART for HIV positive pregnant women in need of treatment. Prophylactic ARV to be given to prevent HIV transmission from mother to child. Universal screening of all pregnant women is cost effective and has demonstrated reduction in HIV mother to fetal transmission even in low prevalence setting.

The present study is done to know the magnitude and trend of prevalence of HIV infection amongst antenatal women in our set-up. In India, estimated number of people living with HIV is 1.8-2.9 million out of which 
$39 \%$ are women with average national prevalence of $0.35 \%$ as assessed from antenatal clinics. ${ }^{3}$ Pregnant women are at a higher risk to HIV infection because of decreased immunoglobulin complement and a more significant decrease in cell mediated immunity during pregnancy. ${ }^{4-7}$

Objective of present study was to know the prevalence of HIV infection in Antenatal women attending a tertiary care hospital and to know the trend over the five years in the magnitude of this infection.

\section{METHODS}

This is a retrospective study in a tertiary care hospital. It included all pregnant females reported in the OBGY department from April 2012 to March 2017. For all females first pre-test counseling done by a trained counselor, informed and written consent was taken and blood sample collected. The sample after process is tested as per NACO guidelines. ${ }^{8}$ The first is done by Rapid test. If the initial result is positive then it is confirmed using rapid test twice. If all three tests are positive then patient is confirmed as HIV positive. After the test, post-test counseling is done. The results of the test are disclosed only after counseling to the patient and is kept confidential. In case the females are tested positive the partners testing is also done. The results of which are also kept confidential. The HIV positive antenatal woman undergoes CD4 count and started treatment as per recent NACO guidelines. Proper antenatal care is given and hospital delivery is advised.

Data collected is statistically analyzed by number and percentage distribution.

\section{RESULTS}

The above table shows the trend of positive cases over last five years in a tertiary care hospital. The seroprevalence shows a gradually decreasing trend due to increased public awareness and various AIDS control measures by the Government.

Table 1: Prevalence of HIV Infection in antenatal women from April 2012 to March 2017.

\begin{tabular}{|llll|}
$\begin{array}{l}\text { Year } \\
\text { (Apri- } \\
\text { March) }\end{array}$ & $\begin{array}{l}\text { No. of } \\
\text { Antenatal cases } \\
\text { registered }\end{array}$ & $\begin{array}{l}\text { No. of } \\
\text { Seropositive } \\
\text { cases }\end{array}$ & $\%$ \\
\hline $2012-2013$ & 7068 & 33 & 0.466 \\
\hline $2013-2014$ & 7841 & 17 & 0.216 \\
\hline $2014-2015$ & 7615 & 15 & 0.196 \\
\hline $2015-2016$ & 7481 & 05 & 0.066 \\
\hline $2016-2017$ & 7189 & 20 & 0.278 \\
\hline
\end{tabular}

The results are also comparable to National prevalence of $0.35 \%$. In the study conducted from 2003-2006 in Northern India, the seroprevalence among pregnant women in a tertiary hospital has been found to be $0.88 \% .^{5}$
Majority of women in the present study are in the age group of 21-25 years. This is also comparative to other studies observed in Northern India and Nagpur where it was $46.94 \%$ and $41.94 \%$ respectively. The main reason is due to peak reproductive years where the females are sexually active and prone to infections from their partners.

Table 2: Distribution of patients according to risk factors.

\begin{tabular}{|llll|}
\hline Factors & & $\begin{array}{l}\text { No. of } \\
\text { patients N=90 }\end{array}$ & $\%$ \\
\hline $\begin{array}{l}\text { Age group } \\
\text { (in years) }\end{array}$ & $<20$ & 06 & 6.66 \\
\hline & $21-25$ & 46 & 51.11 \\
\hline & $26-30$ & 28 & 31.11 \\
\hline & $>30$ & 10 & 11.11 \\
\hline Husband & Reactive & 51 & 56.66 \\
\hline HIV status & Non-reactive & 39 & 43.33 \\
\hline Parity & Primi & 53 & 58.88 \\
\hline & Para 2 & 26 & 28.88 \\
\hline & Para 3 & 07 & 7.77 \\
\hline & Para 4 & 04 & 4.44 \\
\hline Residence & Urban & 44 & 48.88 \\
\hline & Rural & 46 & $51.11 \mathrm{~s}$ \\
\hline
\end{tabular}

The spouse of 51 cases are also tested positive which suggests the source of infection to the females. Majority i.e. $58.88 \%$ are primi para. But with increasing parity the number of cases are less. This might be due to various family planning measures adopted by the females and offered under Government Programmes. Urban and rural population seems to be equally affected in the present study..$^{9,10}$

\section{DISCUSSION}

The present study shows the seroprevalence over the last five years i.e. from April 2012 to March 2017 which lies between $0.46 \%$ to $0.278 \%$. The prevalence rate of HIV among the adult population has continued a steady decline at the national level from an estimated peak of $0.4 \%$ in 2000 down to $0.26 \%$ in $2015 .^{8}$ India has successfully achieved the sixth millennium development goal of halting and reversing the HIV infection. The predominant age group in which there is high prevalence is 21-25 years during which the females are more vulnerable due to increased sexual activity. The prevalence rate among rural and urban population patients came to be roughly same in our study. This might be due to location of the hospital which drains patients from all regions. In a study done on pregnant women in Nigeria, the incidence of HIV infection is more among higher class urban females because affluent attract a lot of social activity which may lead to unprotected sexual activities especially among husbands who pass the infection to their wives. ${ }^{9}$ Approximately in $51 \%$ cases husbands of the females tested reactive which may be the 
source of infection. In a study conducted in Nagpur, Maharashtra, higher seropositivity $96.59 \%$ was observed in the spouses of such patients. ${ }^{11}$ Therefore, routine screening of HIV is advocated for spouses of all women registered in antenatal clinics. $58.88 \%$ are primigravida in the present study. Similar findings were recorded by researchers from Andhra Pradesh and Maharashtra where majority of patients i.e. $53.83 \%$ and $64 \%$ respectively were primigravidas..$^{5}$ This may be due to various delivery practices in our country where still home delivery is prevalent. Secondly once delivered these females might adopt family planning measures as proper counseling is done in our institute.

\section{CONCLUSION}

The above study stresses the core areas like education, health awareness, behavioural changes, protected sexual intercourse and routine screening of all pregnant women will help in the coming years to reduce HIV transmission especially from parent to child. Comprehensive maternal and child health services (Antenatel, Postnatal and child health), voluntary, confidential counselling and testing, Anti-retroviral prophylaxis are various means the Government has adopted to check the spread of HIV infection in the masses. The outcome of all these efforts is definitely reflecting in the prevalence rate in the present scenario.

Funding: No funding sources

Conflict of interest: None declared

Ethical approval: The study was approved by the Institutional Ethics Committee

\section{REFERENCES}

1. NACO Annual Report, 2014-15:404. Available at http://www.naco.gov.in/sites/default/files/annual report/20_NACO_2014-15_0.pdf/Accessed on 12 Jan 2016.

2. National strategic plan, GOI, MOHFW, May 2013 guidelines.

3. Jensin LP, Sullivan MJ, Rao GM. Acquired immune deficiency syndrome in pregnancy. Am. J Obstet Gynecol. 1984;148(8):1145-6.

4. Patel SK, Kansara V, Anand N, Muchhadia J, Patel R, Kagathra B et al. Prevalence of HIV in antenatal women at GMERS Medical College, Sola, Ahmedabad. Int J Reprod Contracept. Obstet Gynecol. 2014;3:662-5.

5. Falhana A, Sarawathi KS. The Study of seroprevalence of HIV in pregnant women in a tertiary care hospital. South India DC Pharmacia Letter. 2012;4(4):1103-4.

6. Kour G, Gupta S, Khajuria R, Seroprevalence of human immunodeficiency virus and various risk factors responsible for spread of human immunodeficiency virus in pregnant women in Jammu, India. Int J Reprod Contracept Obstet Gynecol. 2016;5:3552-5.

7. National guideline for prevention of parent to child transmission (PPTCT) of HIV 01-05-2013 .pdf. Available

http://www.nac.org.zm/sites/default/files/publication s/NAC $\% 20-$

$\% 20$ National $\% 20$ Monitoring\%20and\%20Evaluation \%20Plan\%20\%282011\%E2\%80\%932015\%29.pdf

8. National HIV counseling and testing services guidelines, Dec.2016(1).pdf. Available at http://upsacs.in/UploadedFiles/UpdateSectionDirecto ry/National\%20HIV\%20Counselling\%20\&\%20Testi ng\%20Services\%20Guideline,\%20Dec\%202016_0b 2c15115-28be-4362-b9e0-dd86977e5b3e.pdf.

9. Imade P, Kennedy I, Eghafone N, Enabulele O, Ophori E. HIV seroprevalence among pregnant women attending antenatal clinic in a tertiary health institution in Benin city, Nigeria. Maced J Med Sci. 2010;3(1):43-5

10. Ashtagi GS, Metgud CS, Walvekar PR, Naik VA. Prevalence of HIV among pregnant women attending PPTCT services at KLE hospital, Belgaum, India. Al Ameen J Med Sci. 2011;4(1):45-8

11. Pawan MV, Suresh LH, Rajaram MP, Seroprevalence of human immunodeficiency virus infection in pregnancy in a tertiary care hospital. Indian J Med Sci. 2005;59(9):382-7.

Cite this article as: Jain M, Nimavat BK. To study the prevalence of HIV infection amongst antenatal women in a tertiary care hospital in Gujarat, India. Int J Reprod Contracept Obstet Gynecol 2017;6:3872-4. 